\title{
DOES FOREIGN INVESTMENT CONTRIBUTE TO NATIONAL WEALTH AND SUSTAINABLE ECONOMIC DEVELOPMENT?
}

Summary. The purpose of this article is to analyze the role of foreign investment in contributing to national wealth growth and sustainable economic development, taking into consideration the twofold nature of foreign investment and ambiguous empirical data on its positive impact on economic growth. On the basis of World Bank accounting approach, the author has developed the net foreign assets structure and has analyzed the chain relationships occurring during the estimation of economic sustainability. Having analyzed the core literature concerning effects of international investment on economic well-being of developed and developing countries, the author suggested her own vision of the positive effects of international investment on components of national wealth. On the basis of individual 4-indicators approach for sustainable development outlook, the author came to conclusion that foreign investment plays little role in national wealth growth for selected OECD countries. Despite the fact these countries have required absorptive capacity, small share of foreign investment in national wealth structure is explained by insufficient compliance of foreign capital to sustainability characteristics determining sustainable foreign investment, which, therefore, arises the question of development of unified indicative list of sustainability characteristics to be used by governments attracting foreign capital inflows. Therefore, sustainable foreign investment is characterized by positive impact on human capital through boosting local education, as well as productive capital through the import of high technologies and their emulation into domestic production process. Foreign investment leads to government debt increase, if not absorbed by structural elements of national wealth.

Keywords: foreign investment, sustainable foreign investment, FDI, national wealth, capital, human capital, productive capital, net foreign assets, sustainable economic growth, sustainable development.

Кириченко С.M. Київський національний університет імені Тараса Шевченка

\section{ВПЛИВ СПЕЦИФІКИ ІНОЗЕМНИХ ІНВЕСТИЦІЙ НА ЗРОСТАННЯ НАЦІОНАЛЬНОГО БАГАТСТВА ТА ДОСЯГНЕННЯ СТАЛОГО ЕКОНОМІЧНОГО РОЗВИТКУ}

Анотація. У даній статті досліджуеться роль іноземних інвестицій як структурного елемента національного багатства в досягненні сталого економічного розвитку розвинених країн, беручи до уваги двоякий характер іноземних інвестищій, зокрема неоднозначні емпіричні дані про їх позитивний вплив на економічне зростання. На основі підходу Світового банку до обліку національного багатства, автор зобразив структуру чистих іноземних активів та проаналізував ланцюгові взаемозв'язки, що виникають під час ощінки економічної сталості країни. Розглянувши основну економічну літературу, присвячену впливу міжнародних інвестищій на економічний добробут розвинених країн та країн, що розвиваються, автор запропонував власне бачення позитивних наслідків міжнародних інвестицій на структурні елементи національного багатства, а також навів приклади можливих негативних наслідків для країн, що мають несприятливі умови для їх поглинання. Автор запропонував використовувати 4 ключові показники, що, на його думку, відображають економічний прогрес країн, відповідність їх державних економічних політик та довгострокових стратегій зростання цілям сталого розвитку. Автор дійшов висновку, що іноземні інвестиції відіграють незначну роль у зростанні їх нащіонального багатства, незважаючи на те, що дані країни мають сприятливе середовище для поглинання іноземних інвестицій із подальшим уникненням негативних ефектів від залучення іноземного капіталу. Автор погоджуеться з панівною думкою економістів Світового банку та ОЕСР, що дане явище можна пояснити недостатньою відповідністю іноземного капіталу характеристикам «сталих іноземних інвестицій», що, однак, ставить питання про розробку уніфікованого переліку таких характеристик, які, в свою чергу, мають використовувати уряди для залучення іноземних інвестицій. Таким чином, сталі іноземні інвестиції характеризуються позитивним впливом на розвиток людського капіталу, а також виробничого капіталу за рахунок імпорту високих технологій та їх емулящії у процес вітчизняного виробництва. Іноземні інвестиції призводять до зростання державного боргу, а не національного багатства, якщо вони не поглинаються його структурними елементами.

Ключові слова: іноземні інвестиції, сталі іноземні інвестиції, ПІІ, національне багатство, капітал, людський капітал, виробничий капітал, чисті іноземні активи, стале економічне зростання, сталий розвиток.

Tntroduction. Since the publication of Our

Common Future report, by the World Commission on Environment and Development, headed by Gro Harlem Brundtland, "a new era of environmentally sustainable sound economic development" has started [1]. The global demand for sustained human wellbeing, achieved through greater transparency on environmental, social and governance disclosure [2], has raised the question of measuring sustainable development and developing agreed forward-looking macroeconomic indicator. Taking into account the absence of such unified agreed-upon indicator, as well as the wide range of indicators existing in national and international policy-based sets, the World Bank current solution to the challenge seems relevant. The World Bank uses wealth and wealth per capita as "to be improved" indicators of sustainability, which can accurately mea- 


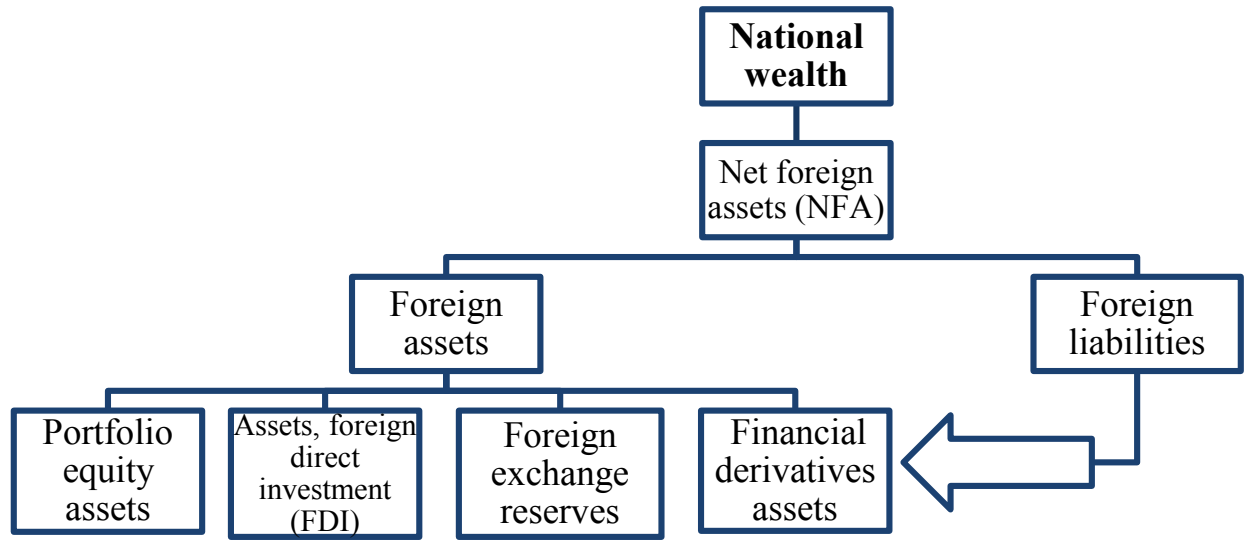

Figure 1. Net foreign assets structure

Source: developed by the author, based on the World Bank wealth accounting approach

sure economic progress and complement GDP. The World Bank approach aims to facilitate countries' statistical agencies with further improvements in measuring sustainable development: "measuring changes in wealth permits us to monitor the sustainability of development, an urgent concern today for all countries, and a critical, yet-to-be-defined indicator for the Sustainable Development Goals".

National wealth accounting is crucial for tracking countries sustainability. It serves as an integral indicator for sustainable development, reflecting the country's overall long-term resource and economic potential in the form of assets. Developed by the World Bank, wealth indicator is aimed to support the Sustainable Development Goals (SDGs), particularly SDG 17: strengthen the means of implementation and revitalize the global partnership for sustainable development [3]. Seeking to provide more comprehensive picture of economic growth, the World Bank collects data of four capital types for 141 countries between 1995 and 2014: financial capital (net foreign assets), produced capital (machinery, buildings, equipment), human capital (present value of a labor force's future earnings).

Net foreign assets is one of the key structural elements of national wealth. The World Bank gives the following determination: net foreign assets (NFA) are the sum of foreign assets held by monetary authorities and deposit money banks (FA), less their foreign liabilities (FL). The generalized calculation formula is as follows: $N F A=F A-F L$ [4]. The NFA structure is provided in Figure 1 below according to the World Bank wealth accounting approach:

Net foreign assets are also included in OECD core set of sustainable development indicators, designed to compare countries and to conduct peer reviews of economic performance and policies [5]. Moreover, foreign investment attraction is set to be the only way to address social, economic and environmental challenges in terms of 2030 Agenda for Sustainable Development. UNCTAD estimates that current Goals-related investments in developing countries by both the public and private sector account for $\$ 1.4$ trillion, and the total annual investment needs to accomplish the Goals by 2030 are around $\$ 3.9$ tril- lion. This leaves an annual gap of $\$ 2.5$ trillion which public sector is unable to fulfill [6]. Foreign direct investment remains the largest source of external finance for developing and the least developed countries, and the only source of high-technology import. The impact of NFA on sustainable economic development may be described as follows (Figure 2).

Purpose of the article. The purpose of this article is to analyze the role of foreign investment in contributing to national wealth growth and sustainable economic development, taking into consideration the twofold nature of foreign investment and ambiguous empirical data on its positive impact on economic growth.

Literature review. Despite foreign investment attraction still remains one of the key recommendations of international financial institutions (IMF, the World Bank) for economic growth and development, the benefits of foreign capital for developing economies have long been disputed both inside and outside the mainstream economics. The standard neoclassical Solow-Swan model (1956) [7] predicts possibility of developing countries to catch up with the industrialized world by increasing the share of savings, especially in human capital, however, in practice non-industrial countries faced debt servicing problems, economic slowdown and decreasing human productivity. With replacement of Solow exogenous model by Lucas endogenous growth model (1988) [8], the emphasis was made on FDI as technologies transfer process. Empirical evidence proved that long-term economic growth is achieved by technical progress (Abramovitz 1956 [9]; Solow 1957 [10]) not capital or investment, which makes foreign investment ineffective instrument for raising savings, if it does not enhance local learning and

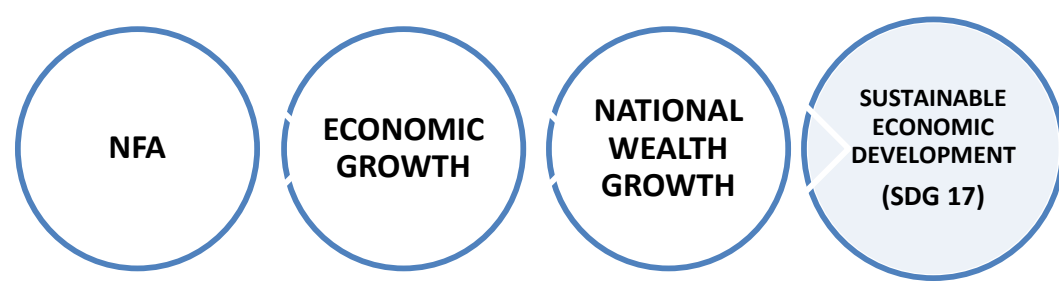

Figure 2. Chain relationships occurring when measuring economic sustainability

Source: developed by author 
technology emulation. Moreover, some economists (Gourinchas and Jeanne 2013 [11]) argued that the capital flows from the poor countries to the rich. This is true for human capital, the most valuable wealth component (Figure 3, Table 5), which accounts for $64 \%$ of global wealth and is measured as the value of earnings over a person's lifetime [12]. In contrast to human capital, the share of net foreign assets is negative, indicating extensive rise of global debt (up to $\$ 246.5$ trillion, almost $320 \%$ of global economic output in 2019) since 2009 financial crisis [13].

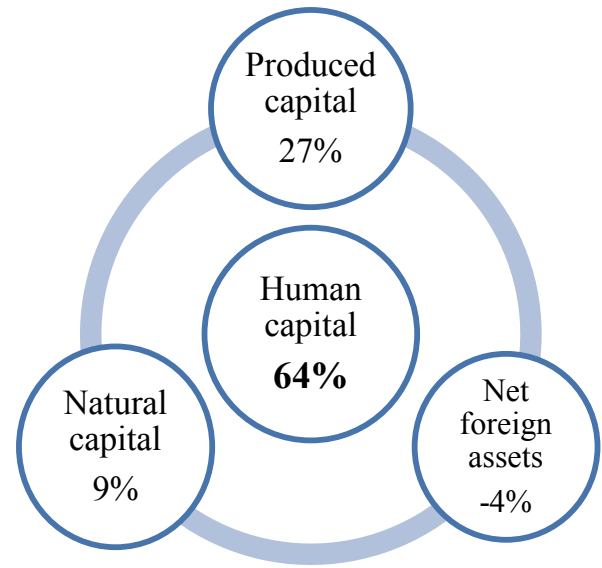

Figure 3. Total wealth by asset class in the world (constant 2014 US\$)

Source: developed by the author with the use of Databank Wealth Accounts. Access mode: https://databank.worldbank.org/reports.aspx? source $=$ wealth-accounts \#

Whilst modernization hypothesis based on neoclassical and endogenous growth theories consider FDI as a panacea to the host country, an alternative view, based on dependency theory, suspects that foreign capital inflow is detrimental to growth and cannot substitute indigenous growth strategy. The huge influx of FDI capital inflows to developing countries is considered as a new wave of colonialism and imperialism. Thus, FDI acts as a tool of exploitation (V. Bornschier, C. Chase-Dunn 1985 [14]) that adversely affects the growth prospect of developing world by crowding-out and displacing domestic investment [15].

The key reason for this is that foreign capital tends to take control over the poor country's strategic resources with no innovative technology assimilation, which would otherwise have positive effect on human capital development and productivity levels. Moreover, it may lead to severe economic drawbacks since non-industrialized countries compete globally with one another ensuring favorable investment climate: tax benefits, subsidies, weak environmental and labor standards etc. As far as the neoclassical growth model insists on raising savings for capital accumulation and growth, there is the constant need for developing countries to borrow savings from abroad. J.B. Carbonell and R.A.Werner [16] argue that many developing countries had to incur large foreign-denominated debts, which are hard to service and not rarely resulted in foreign control over their most valuable resources. Thus, foreign capital attraction may have twofold results for national economy. M. Aslam, G. Hassan and S. A. Sakar [17] draw the conclusion that foreign investment attraction may be disadvantageous for developing countries in the long run for the reasons that FDI most likely stimulates less local learning than might the import of technology to be adapted to local uses. Moreover, foreign investment may pose risks of increasing social inequality (Hughes 1979 [18]; Dixon and Boswell 1996 [19]; Kentor 1998 [20]).

The IMF expert opinion is that the reason for the positive impact (advanced technology, managerial experience, competition) in developed countries and negative spillovers in developing countries lies in the limited ability of non-industrial countries to absorb foreign capital. H. Nguyen, G. Duysters, J. Patterson, H. Sander [21] emphasize that FDI benefits occur only when the host country has specific conditions to absorb them. They suggest that the host country should have developed financial system, favorable conditions for education of local population, well-developed physical infrastructure, $R \& D$, and institutions in order to absorb the FDI spillovers for national economic growth. Thus, the FDI absorption is more essential than FDI attractiveness, as evidenced by the Lucas paradox (1990) [22].

Despite moderate increase of FDI flows to developing countries in 2010-2015, influenced by economic slowdown of developed economies hit by global financial crisis, the outflow of human capital, one of the scarcest resources of the third world economies, has remained a main drag in economic development and national wealth accumulation. If we consider human capital as one of the most valuable assets, thus, the brain drain from developing countries is another evidence of Lucas paradox in the $21^{\text {st }}$ century. Additionally, sharp decrease of investment flows since 2016 poses significant risk to stability in African and Asian regions and confirms the general trend: developed economies remain investment havens and attract talent from less developed areas.

According to OSCE 2019 report "The contribution of international business investment to the Sustainable Development Goals" [23], the era of FDI prosperity for developing countries is over. 2008 financial crisis led to decline in global FDI flows by 40 per cent to USD 1.2 trillion in 2009 from USD 2 trillion in 2007 (Figure 4). 2010 recovery was mainly due to 60 per cent increase in flows to the developing economies, reaching the historical record of around USD 900 billion in 2015. This period of 'FDI prosperity' ended in 2016, when FDI flows reversed course at the global level. In 20162017, the global decrease by over 30 per cent was due to broad cyclical and country-specific factors, i.e. various sources of geopolitical instability, concerns over rising protectionism, and record levels of corporate debt in the emerging markets. Improved economic conditions in developed countries led to decline of inflows to developing economies by USD 218 billion, or 24 per cent.

Karl P. Sauvant, Resident Senior Fellow, (Columbia Center on Sustainable Investment, Columbia University) states that foreign investment can become a powerful international mechanism for mobilizing tangible and intangible assets (such as capital, technology, skills, access to markets) that would contribute to sustainable development [24]. He defines three key challenges towards attainment of sustainable foreign direct investment globally: 


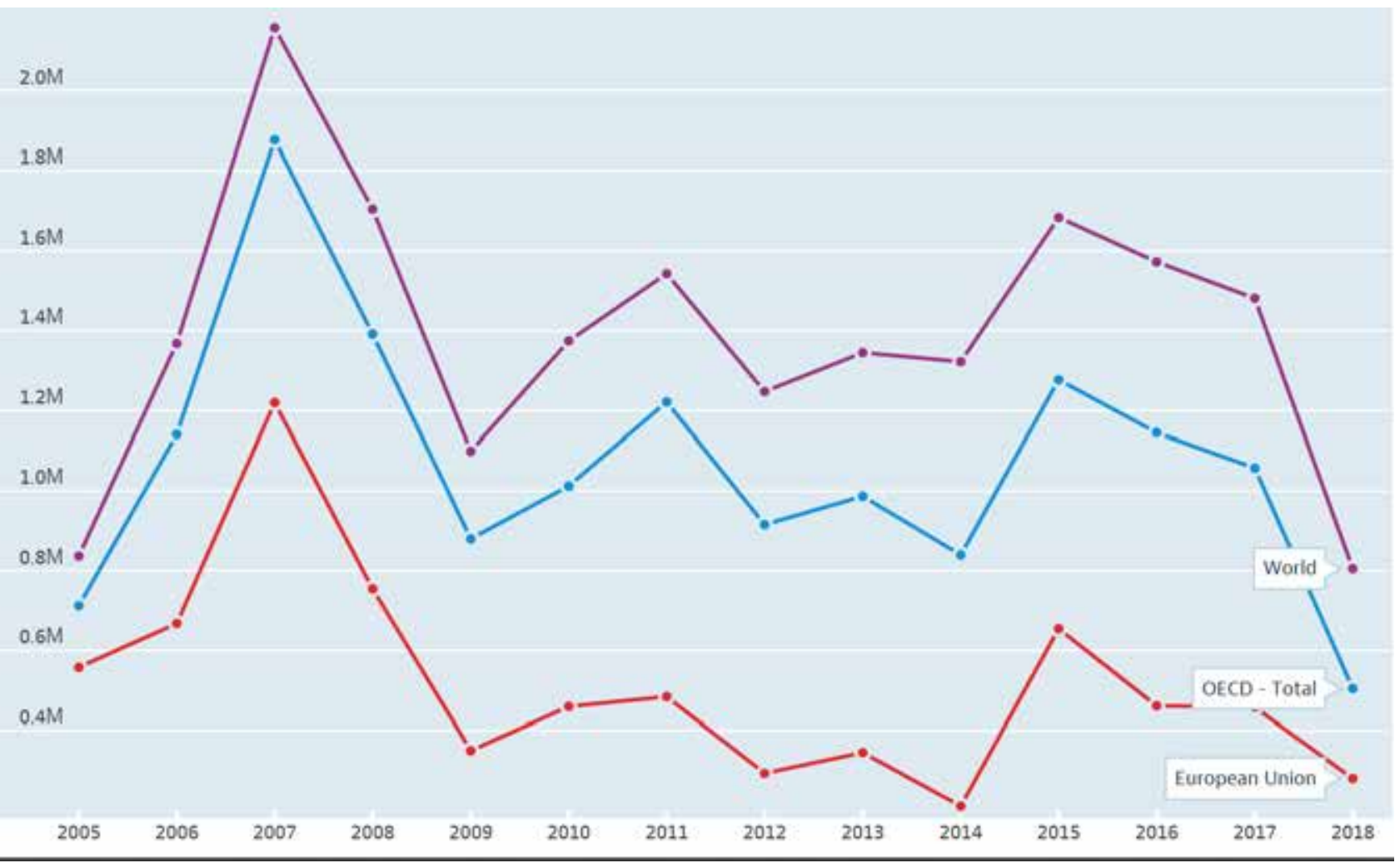

Figure 4. FDI flows (million US dollars, 2005-2018)

Source: Benchmark definition, 4th edition (BMD4): Foreign direct investment: financial flows, main aggregates. Access mode: https://data.oecd.org/fdi/fdi-flows.htm

1. Ensuring substantial investment increase in order to fulfill global investment needs in the future perspective (up to USD 4 or 5 trillion annually).

2 . Defining "sustainable foreign direct investment", which requires development of an indicative list of sustainability characteristics to be used by governments seeking to attract sustainable foreign direct investment (and to encourage sustainable domestic investment).

3. Reforming the international investment law and policy regime, which requires concerted international effort and joint action of key actors: governments and multinational enterprises MNEs [24].
Figure 5 below summarizes potential benefits from sustainable foreign investment for national wealth structural components.

E.S. Prasad (Cornell University), R.G. Rajan (University of Chicago), and A. Subramanian (IMF) indicate the main reasons for FDI spillovers: national financial systems' failure to allocate FDI to productive uses, and exchange rate appreciation (and, often, overvaluation) when faced with such foreign capital inflows. Both effects have detrimental effect to the national economy growth: overvalued exchange rates lead to shift decrease of manufacturing exports, while underdeveloped financial system

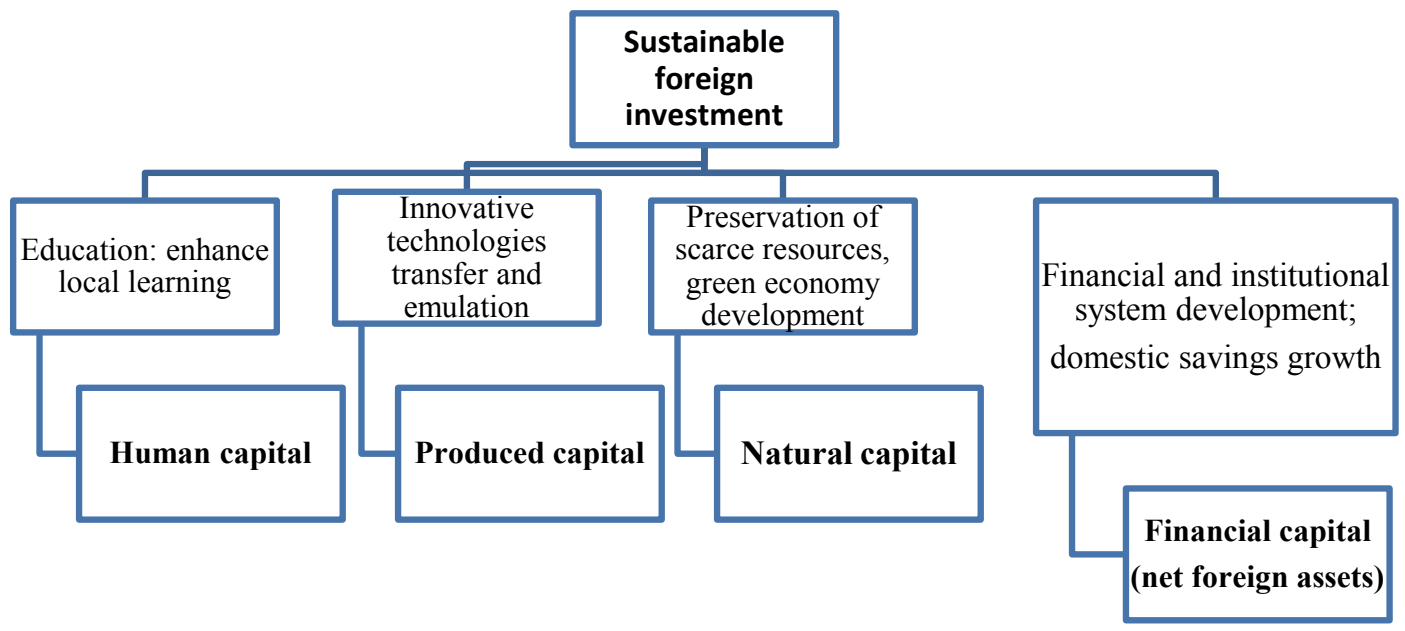

Figure 5. Sustainable foreign investment positive impact (benefits) on national wealth structural components 
channels capital to easily collateralized non-tradeable investments (e.g. real estate) instead of highly-productive but hard-to-finance investment [25].

Bearing in mind the ambiguous impact of foreign capital on domestic economy growth, the main issue is to analyze "foreign investment $\rightarrow$ national wealth $\rightarrow$ sustainable development" relation. Does foreign investment contribute to national wealth and, consequently, to sustainable development? Most studies examine the FDI impact on developing countries, while research for group or separate developed countries shows either positive (Leichenko and Erickson 1997 [26]; A. Kokko 2006 [27], T.H. Moran 2003 [28]), negative (Carkovic and Levine 2005 [29]; Johnson 2006 [30]; Türkcan, Duman, and Yetkiner 2008 [31]; J.B. Carbonell, R.A.Werner 2018 [16]) or inconclusive effect (Robert E. Lipsey 2002 [32], De Mello 1999 [33]) on economic growth. However, there is no current macroeconomic research, which would examine its impact on national wealth of developed economies.

Of particular interest is research held by J.B. Carbonell and R. A. Werner concerning impact of FDI on boosting economic growth in Spain within observation period 1984-2010 [16]. Having used new empirical approach including the role of bank credit for the real economy, authors came to conclusion that FDI had no significant positive effect on Spanish GDP growth from 1984 to 2010, despite both high FDI and economic growth, as well as the most favorable conditions (developed financial markets, skilled labor, etc.) for FDI to boost economic growth. Authors summarize that Spanish economic growth was rather due to stimulation of productive domestic credit creation, employment, foreign demand, and education and suggest that the government would better no waste Spanish taxpayers funds on attracting foreign capital and spend more on domestic education instead.

Methodology. This article provides research for OECD developed economies since they remain key investment havens in the world. Author suggests using the following indicators for sustainable development outlook: wealth per adult (Table 1, 2); Gini index (Table 3), net foreign assets (Table 4) and high-skilled migration data (Table 5). The following indicators demonstrate the countries' economic progress and the correspondence of their state economic policies and long-term growth strategies to sustainable development goals. The author has selected 10 wealthiest OECD countries by wealth per adult indicator (Table 1). Table 2 shows general positive trend in wealth dynamics for those countries from 2010-2018, but still some of them face problems with attaining stable wealth growth (France, Norway, Belgium).

Gini index is crucial for sustainability analysis, as it shows how income is distributed within the country: the greater the difference in income distribution in society, the higher is the index value. Gini index data, provided by Credit Suisse World inequality database for selected countries (Table 3), is applied here for comparison with wealth indicator, in order to demonstrate how the wealthiest national economies improve their wellbeing and adhere to sustainable guidelines. One should take into account that the Credit Suisse index values are much higher than values provided by the
World Bank database, which can be explained by approach and initial data differences. The author decided to take the highest values for research to get more objective outcome. Correlation between the wealth and Gini indices proves effectiveness of government economic policy, in particular country's sustainable development strategy (if available) and ability to respond to current global social, economic and environmental crises. Countries with the most complete annual statistics were selected. Table 3 shows that countries with high per capita wealth have stable economic growth in accordance with the principles of sustainable development, as well as effective system of institutions, which ensures relatively even income distribution, thus preventing social inequality. However, the world inequality level remains high due to developing countries exclusive-growth strategies.

Table 4 contains net foreign assets data for 2005, 2010 and 2014 periods. A negative NFA value suggests that country is running down its capital stocks and thereby possibly reducing future social welfare; a positive ANS suggests that a country is adding to its wealth and thereby its future well-being. Among the countries selected, three of them (USA, Australia, France) have weak net foreign asset (NFA) position being rather borrowers than lenders of a wealth transfer. In general, OECD countries are doing pretty well comparing to the world lack of foreign investment to overcome continuously increasing world debt.

Table 5 shows significant source of human capital increase, both for EU countries facing demographic crisis, and countries (USA, Canada, New Zealand), which population growth closely related to migration inflow. The Brain drain database of Research Institute of the Federal Employment Agency contains data on the total number of foreign-born individuals aged 25 years and older, living in each of the 20 considered OECD destination countries, by year, gender, country of origin and educational level. Educational levels are distinguished in low, medium and high skilled. Statistics are available for 8 selected OECD countries, where the wealth per adult is the highest in the world (Table 5).

Table 5 shows that the abovementioned countries have stable migration inflow of high-skilled workers coming from post-Soviet (Kazakhstan, Russia, Georgia, Belarus, Ukraine), Latin America (Argentina, Brazil etc.), developing Asian (China, Vietnam, Indonesia) and African countries (Mozambique, South Africa), which means negative outcomes for labor force donors, i.e. human capital losses.

Results and findings. Having analyzed the data of four sustainable indicators, the author has come to conclusion that OECD countries do have required absorptive capacity in order to cope with FDI spillovers, therefore the impact of foreign investment on economic growth is either positive or neutral (assets/liabilities ratio $=0$ ). However, does foreign investment significantly contribute to national wealth growth? Table 6 bellow shows that net foreign assets play insignificant role in national wealth growth, consisting less than $10 \%$ in each selected country except Singapore. The main wealth structural component is human capital, which varies from $60 \%$ (Singapore, Norway) up to $78 \%$ (USA). 
Top 10 wealthiest countries by wealth per adult, 2018

Table 1

\begin{tabular}{|c|c|c|c|c|c|}
\hline \multirow{2}{*}{ No. } & \multirow{2}{*}{ Country } & Total wealth & Wealth per adult & $\begin{array}{c}\text { Number of } \\
\text { millionaires }\end{array}$ & Adults \\
\cline { 3 - 6 } & & USD bn & USD bn & thousand & thousand \\
\hline 1 & Switzerland & 3,611 & $\mathbf{5 3 0 , 2 4 4}$ & 725 & 6,811 \\
\hline 2 & Australia & 7,577 & $\mathbf{4 1 1 , 0 6 0}$ & 1,288 & 18,433 \\
\hline 3 & USA & 98,154 & $\mathbf{4 0 3 , 9 7 4}$ & 17,350 & 242,972 \\
\hline 4 & Belgium & 2,776 & $\mathbf{3 1 3 , 0 4 5}$ & 424 & 8,869 \\
\hline 5 & Norway & 1,181 & $\mathbf{2 9 1 , 1 0 3}$ & 185 & 4,057 \\
\hline 6 & New Zealand & 1,010 & $\mathbf{2 8 9 , 7 9 8}$ & 155 & 3,486 \\
\hline 7 & Canada & 8,319 & $\mathbf{2 8 8 , 2 6 3}$ & 1,289 & 28,858 \\
\hline 8 & Denmark & 1,276 & $\mathbf{2 8 6 , 7 1 2}$ & 243 & 4,450 \\
\hline 9 & Singapore & 1,289 & $\mathbf{2 8 3 , 1 1 8}$ & 184 & 4,552 \\
\hline 10 & France & 13,883 & $\mathbf{2 8 0 , 5 8 0}$ & 2,147 & 49,478 \\
\hline
\end{tabular}

Source: Credit Suisse Global Wealth Report, 2018. Access mode: https://www.credit-suisse.com/about-us/en/reports-research/ global-wealth-report.html

Table 2

National wealth (USD trn) dynamics of top 10 countries by wealth per adult (constant exchange rates, 2000-2018)

\begin{tabular}{|c|c|c|c|c|c|c|c|c|c|c|}
\hline No. & Country & $\mathbf{2 0 1 0}$ & $\mathbf{2 0 1 1}$ & $\mathbf{2 0 1 2}$ & $\mathbf{2 0 1 3}$ & $\mathbf{2 0 1 4}$ & $\mathbf{2 0 1 5}$ & $\mathbf{2 0 1 6}$ & $\mathbf{2 0 1 7}$ & $\mathbf{2 0 1 8}$ \\
\hline 1 & Switzerland & 2,713 & 2,960 & 3,165 & 3,383 & 3,483 & 3,507 & 3,543 & 3,615 & 3,676 \\
\hline 2 & Australia & 5,999 & 6,044 & 6,422 & 6,670 & 6,793 & 6,922 & 7,369 & 7,454 & 7,829 \\
\hline 3 & USA & 60,230 & 61,160 & 66,718 & 76,124 & 80,845 & 83,586 & 88,794 & 91,830 & 98,154 \\
\hline 4 & Belgium & 2,322 & 2,440 & 2,347 & 2,360 & 2,516 & 2,443 & 2,633 & 2,629 & 2,778 \\
\hline 5 & Norway & 1,046 & 1,141 & 1,105 & 1,128 & 1,191 & 1,070 & 1,104 & 1,123 & 1,169 \\
\hline 6 & New Zealand & 661 & 720 & 774 & 822 & 872 & 948 & 1,012 & 995 & 1,053 \\
\hline 7 & Canada & 6,449 & 6,976 & 7,415 & 7,561 & 7,781 & 7,750 & 8,077 & 8,048 & 8,490 \\
\hline 8 & Denmark & 1,045 & 1,041 & 999 & 1,018 & 1,080 & 1,135 & 1,174 & 1,211 & 1,279 \\
\hline 9 & Singapore & 888 & 974 & 1,065 & 1,101 & 1,105 & 1,115 & 1,169 & 1,193 & 1,292 \\
\hline 10 & France & 13,721 & 14,021 & 13,227 & 12,829 & 12,385 & 12,461 & 12,643 & 12,844 & 13,891 \\
\hline & World & $\mathbf{2 3 6 , 6 2 0}$ & $\mathbf{2 4 7 , 1 0 6}$ & $\mathbf{2 5 9 , 6 0 1}$ & $\mathbf{2 7 3 , 1 6 1}$ & $\mathbf{2 7 9 , 4 6 1}$ & $\mathbf{2 8 4 , 9 4 8}$ & $\mathbf{2 9 6 , 5 5 3}$ & $\mathbf{3 0 2 , 3 0 5}$ & $\mathbf{3 1 8 , 8 9 0}$ \\
\hline
\end{tabular}

Source: Credit Suisse. Global Wealth Databook 2018. Access mode: https://www.credit-suisse.com/about-us/en/reports-research/ global-wealth-report.html

Table 3

Gini index for selected countries (2010-2016)

\begin{tabular}{|c|c|c|c|c|c|}
\hline No. & Country & $\mathbf{2 0 1 0}$ & $\mathbf{2 0 1 2}$ & $\mathbf{2 0 1 4}$ & $\mathbf{2 0 1 6}$ \\
\hline 1 & Switzerland & 38 & 38 & 38 & 39 \\
\hline 2 & USA & 59 & 60 & 60 & - \\
\hline 3 & Belgium & 37 & 38 & 38 & 38 \\
\hline 4 & Norway & 32 & 32 & 33 & 32 \\
\hline 5 & Denmark & 35 & 36 & 38 & 38 \\
\hline 6 & France & 43 & 43 & 43 & - \\
\hline & World & $\mathbf{6 6}$ & $\mathbf{6 6}$ & $\mathbf{6 5}$ & $\mathbf{6 5}$ \\
\hline
\end{tabular}

Source: Credit Suisse, World inequality database. Access mode: https://wid.world/news-article/gini-coefficients-available/

Net foreign assets (constant 2014 US\$)

\begin{tabular}{|c|c|c|c|c|}
\hline No. & Country & $\mathbf{2 0 0 5}$ & $\mathbf{2 0 1 0}$ & $\mathbf{2 0 1 4}$ \\
\hline 1 & Switzerland & $\$ 623,499,483,410$ & $\$ 904,626,312,788$ & $\$ 648,543,935,700$ \\
\hline 2 & Australia & $-\$ 627,713,847,301$ & $-\$ 866,476,756,793$ & $-\$ 731,662,580,500$ \\
\hline 3 & USA & $-\$ 2,356,464,335,287$ & $-\$ 3,095,406,936,836$ & $-\$ 7,334,900,963,000$ \\
\hline 4 & Belgium & $\$ 142,983,104,490$ & $\$ 326,774,272,191$ & $\$ 270,516,150,600$ \\
\hline 5 & Norway & $\$ 238,962,775,940$ & $\$ 415,777,875,804$ & $\$ 719,303,303,900$ \\
\hline 6 & Canada & $-\$ 181,777,284,063$ & $-\$ 281,386,826,801$ & $\$ 118,139,728,100$ \\
\hline 7 & Denmark & $\$ 10,381,859,347$ & $\$ 40,258,029,427$ & $\$ 147,312,758,300$ \\
\hline 8 & Singapore & $\$ 491,476,283,312$ & $\$ 552,905,594,388$ & $\$ 672,796,934,400$ \\
\hline 9 & France & $\mathbf{- \$ 9 6 , 6 3 7 , 6 8 6 , 6 5 5}$ & $\mathbf{- \$ 3 4 9 , 1 6 8 , 9 1 0 , 2 1 9}$ & $\mathbf{- \$ 6 0 1 , 8 5 5 , 3 4 0 , 7 0 0}$ \\
\hline & World & $\mathbf{- \$ 3 , 2 8 5 , 3 0 0 , 8 1 5 , 6 9 4}$ & $\mathbf{- \$ 2 , 5 5 6 , 4 2 5 , 2 9 6 , 8 9 0}$ & $\mathbf{- \$ 4 , 5 8 1 , 3 1 8 , 8 6 2 , 4 8 8}$ \\
\hline
\end{tabular}

Source: The World Bank. Wealth Accounting Data Catalog. Access mode: https://datacatalog.worldbank.org/dataset/wealth-accounting 
Table 5 foreign capital and to cope with debt servicing prob-

Highly-skilled migration inflow for selected OECD countries, (\% of migrants with high education from total immigration stock)

\begin{tabular}{|c|c|c|c|c|c|}
\hline No. & Country & $\mathbf{1 9 9 5}$ & $\mathbf{2 0 0 0}$ & $\mathbf{2 0 0 5}$ & $\mathbf{2 0 1 0}$ \\
\hline 1 & Switzerland & $19 \%$ & $22 \%$ & $21.4 \%$ & $22 \%$ \\
\hline 2 & Australia & $42.2 \%$ & $40.3 \%$ & $44.5 \%$ & $49.7 \%$ \\
\hline 3 & USA & $39.3 \%$ & $40 \%$ & $41 \%$ & $42.5 \%$ \\
\hline 4 & Norway & $27 \%$ & $28.7 \%$ & $32.8 \%$ & $36.7 \%$ \\
\hline 5 & New Zealand & $27.9 \%$ & $29.3 \%$ & $40.6 \%$ & $35.6 \%$ \\
\hline 6 & Canada & $46.6 \%$ & $50.8 \%$ & $59.5 \%$ & $68.2 \%$ \\
\hline 7 & Denmark & $22 \%$ & $26 \%$ & $27 \%$ & $24.8 \%$ \\
\hline 8 & France & $12 \%$ & $16 \%$ & $20 \%$ & $22.6 \%$ \\
\hline
\end{tabular}

Source: developed by author on the basis of Brain drain data base. Access mode: https://www.iab.de/en/daten/iab-braindrain-data.aspx

Table 6 National wealth structure by asset classes, 2014 (\%)

\begin{tabular}{|c|c|c|c|c|}
\hline $\begin{array}{c}\text { Top } \\
\text { 10 selected } \\
\text { countries }\end{array}$ & \multicolumn{4}{|c|}{2014} \\
\hline Country & $\begin{array}{c}\text { Produced } \\
\text { capital }\end{array}$ & $\begin{array}{c}\text { Natural } \\
\text { capital }\end{array}$ & $\begin{array}{c}\text { Human } \\
\text { capital }\end{array}$ & $\begin{array}{c}\text { Net } \\
\text { foreign } \\
\text { assets }\end{array}$ \\
\hline Switzerland & $24 \%$ & $1 \%$ & $70 \%$ & $\mathbf{5 \%}$ \\
\hline Australia & $30 \%$ & $17 \%$ & $56 \%$ & $\mathbf{- 3 \%}$ \\
\hline USA & $22 \%$ & $2 \%$ & $78 \%$ & $\mathbf{- 2 \%}$ \\
\hline Belgium & $33 \%$ & $1 \%$ & $63 \%$ & $\mathbf{4 \%}$ \\
\hline Norway & $25 \%$ & $6 \%$ & $60 \%$ & $\mathbf{8 \%}$ \\
\hline Canada & $23 \%$ & $5 \%$ & $72 \%$ & $\mathbf{0 \%}$ \\
\hline Denmark & $32 \%$ & $2 \%$ & $63 \%$ & $\mathbf{3 \%}$ \\
\hline Singapore & $24 \%$ & $0 \%$ & $60 \%$ & $\mathbf{1 6 \%}$ \\
\hline
\end{tabular}

Source: developed by author with the use of World Bank Wealth Accounting Data Catalog

Author assumes that the positive and relatively high NFA values for Switzerland, Belgium, Singapore, and Norway are due to developed financial sector and its high share in GDP output. Still, Australia and USA face problems with attracting foreign investment to cover their domestic needs in lems since both countries debt levels rise steadily since 2007-2010 financial crisis, reaching more than $30 \%$ of GDP in Australia and more than 250\% of GDP in USA.

Conclusions and prospects for further research. Foreign investment can become a powerful mechanism for mobilizing tangible and intangible assets that would contribute to national wealth and sustainable economic growth, and therefore to nations wellbeing. Foreign investment may play both positive and detrimental role for sustainable economic growth and wealth growth.

1. The positive impact of foreign investment on national wealth and economic growth in terms of sustainable development framework is possible when recipient country has specific conditions to absorb foreign capital inflows: developed financial system, favorable conditions for education of local population, well-developed physical infrastructure, R\&D, and institutions. Thus, FDI absorption is more essential than FDI attractiveness.

2 . The ambiguous nature of foreign investment requires application of single-country approach in order to assess its impact on economic performance.

3 . The negative impact of foreign investment, called investment spillovers, include: overvalued exchange rates leading to diminishing exports; national financial systems' failure to allocate FDI to productive uses; national debt increase; negative effects on local environment; foreign control over their most valuable resources; social inequality risk.

4. The main conditions for effective attraction of foreign investment include: high technologies import and emulation; human capital development through increase of domestic learning.

5. Net foreign assets play insignificant role in national wealth growth for developed economies, which testifies that joint action is needed to ensure sustainable foreign direct investment determination and encouragement. Foreign investment leads to government debt increase, if not absorbed by structural elements of national wealth. Subsequent research perspectives include the impact of foreign investment on productive and human capital growth.

\section{References:}

1. Global Community Webnet: Measurement of sustainable development (2019). Retrieved from: http://globalcommunitywebnet.com/globalcommunity/measurementofsd.htm (accessed 31 July 2019).

2. GRI: G4 is future of sustainability reporting, say business leaders (2019). Retrieved from: https://www.globalreporting.org/ information/news-and-press-center/Pages/G4-is-future-of-sustainability-reporting-say-business-leaders.aspx (accessed 29 July 2019).

3. Sustainable Development Knowledge Platform: PROGRESS OF GOAL 17 IN 2019 (2019). Retrieved from: https://sustainabledevelopment.un.org/sdg17 (accessed 1 August 2019).

4. World Bank (2018). Building the World Bank's Wealth Accounts: Methods and Data. World Bank Database. Retrieved from: https://development-data-hub-s3-public.s3.amazonaws.com/ddhfiles/94641/wealth-methodologyjanuary-30-2018_4_0.pdf (accessed 31 July 2019).

5. Stevence C. (2010). Measuring sustainable development. Retrieved from: https://www.oecd.org/sdd/35407580.pdf (accessed 23 July 2019).

6. United Nations. Promoting foreign investment in the Sustainable Development Goals. United Nations Conference on Trade and Development (2017). Retrieved from: https://unctad.org/meetings/en/SessionalDocuments/ciid35_EN.pdf (accessed 1 August 2019).

7. Solow R.M. (1956). A contribution to the theory of economic growth. Quarterly Journal of Economics, 70(1): 65-94. doi: $10.2307 / 1884513$

8. Lucas R.E.Jr. (1988). On the mechanics of economic development. Journal of Monetary Economics, 22(1): 3-42. doi: 10.1016/0304-3932(88)90168-7

9. Abramovitz M. (1956). Resource and output trends in the United States since 1870. American Economic Review, 46(2): 5-23. 
10. Solow R.M. (1957). Technical change and the aggregate production function. Review of Economics and Statistics, 39(3): 312-20. doi: 10.2307/1926047

11. Gourinchas P.-O., Jeanne O. (2013). Capital flows to developing countries: The allocation puzzle. Review of Economic Studies, 80(4): 1484-515. doi: 10.1093/restud/rdt004

12. World Bank. Wealth accounting database (2019). Retrieved from: https://openknowledge.worldbank.org/bitstream/ handle/10986/29001/9781464810466.pdf?sequence=4\&isAllowed=y (accessed 3 August 2019).

13. The global debt binge begins anew (2019). Retrieved from: https://www.axios.com/global-debt-increase-q1-201992ef0a63-b86e-471d-84c8-588a719f3fc2.html (accessed 6 August 2019).

14. Bornschier V., Chase-Dunn C. (1985). "Transnational corporations and underdevelopment". New York : Praeger.

15. Syed Hasanat S., Hafsa H., Junjiang L. (2010). Does foreign capital inflows really stimulate domestic investment: a case study of Pakistan. Retrieved from: https://mpra.ub.uni-muenchen.de/35737/1/Does_Foreign_Capital_ Inflows_really_Stimulate_Domestic_Investmen_A_case_study_of_Pakistan_pdf/ (accessed 6 August 2019).

16. Jorge Bermejo Carbonell \& Richard A. Werner (2018). Does Foreign Direct Investment Generate Economic Growth? A New Empirical Approach Applied to Spain, Economic Geography, 94:4, 425-456, doi: 10.1080/00130095.2017.1393312

17. Gulam Hassan, Mohamed Aslam and Abou Sakar, Sameer (2013). Foreign Direct Investment, Human Capital and Economic Growth in Malaysia. Retrieved from: https://mpra.ub.uni-muenchen.de/51930/ (accessed 8 August 2019).

18. Hughes H. (1979). Debt and development: The role of foreign capital in economic growth. World Development, 7(2): 95-112. doi: 10.1016/0305-750X(79)90026-3

19. Dixon W.J., Boswell T. (1996). Dependency, disarticulation, and denominator effects: Another look at foreign capital penetration. American Journal of Sociology, 102(2): 543-62. doi: 10.1086/230956

20. Kentor J. (1998). The long-term effects of foreign investment dependence on economic growth, 1940-1990. American Journal of Sociology, 103 (4): 1024-46. doi: 10.1086/231295

21. Nguyen H., Duysters G., Patterson J., Sander H. (2019). Foreign Direct Investment Absorptive Capacity Theory. Retrieved from: https://pdfs.semanticscholar.org/e874/090250c67484e6ffdbc5fd670a2c821f5832.pdf (accessed 8 August 2019).

22. Lucas R.E.Jr (1990). Why doesn't capital flow from rich to poor countries? American Economic Review, 80(2): 92-96.

23. OECD (2019). The contribution of international business investment to the sustainable development goals. Retrieved from: http://www.oecd.org/investment/investment-policy/The-contribution-of-international-businessinvestment-to-the-sustainable-development-goals.pdf (accessed 8 August 2019).

24. (2019). How can foreign direct investment fulfil its development potential? OECD. Retrieved from: https://oecdonthelevel.com/2019/04/10/the-challenge-how-can-foreign-direct-investment-fulfil-its-developmentpotential/ (accessed 8 August 2019).

25. Eswar S.P., Raghuram G.R., Arvind S. (2007). Foreign Capital and Economic Growth. Retrieved from: https://www.piie.com/sites/default/files/publications/papers/subramanian0407.pdf (accessed 8 August 2019).

26. Leichenko R.M., Erickson R.A. (1997). Foreign direct investment and state export performance. Journal of Regional Science, 37 (2): 307-29. doi: 10.1111/jors.1997.37.issue-2

27. Kokko (2006). The Home Country Effects on FDI in Developed Economies Working paper No. 225. Retrieved from: https://www.researchgate.net/publication/5094545_The_Home_Country_Effects_Of_Fdi_In_Developed_Economies (accessed 8 August 2019).

28. T.H. Moran (2005). How Does FDI Affect Host Country Development? Using Industry Case Studies to Make Reliable Generalizations. Retrieved from: https://www.piie.com/publications/chapters_preview/3810/11iie3810.pdf (accessed 7 August 2019).

29. Carkovic M., Levine R. (2005). Does foreign direct investment accelerate economic growth? In Does foreign direct investment promote development? ed. T.H. Moran, E.M. Graham, and M. Blomström, 195-220. Washington, DC : Institute for International Economics.

30. Johnson A. (2006). The effects of FDI on host country economic growth. Working Paper 58. Stockholm, Sweden : Royal Institute of Technology, Centre of Excellence for Studies in Science and Innovation.

31. Türkcan B., Duman A., Yetkiner I.H. (2008). How does FDI and economic growth affect each other? The OECD case. International Conference on Emerging Economic Issues in a Globalizing World, Izmir, Turkey, May 25. http://eco.ieu.edu.tr/wp-content/proceedings/2008/ 0802.pdf (accessed 8 August 2019).

32. Robert E. Lipsey. Home and host country effects on FDI (2002). Working paper 9293. National Bureau of Economic Research. Retrieved from: https://www.nber.org/papers/w9293.pdf (accessed 6 August 2019).

33. De Mello L.R. (1997). Foreign direct investment in developing countries and growth: A selective survey. Journal of Development Studies, 34 (1): 1-34. doi: 10.1080/00220389708422501; 1999. Foreign direct investment-led growth: Evidence from time series and panel data. Oxford Economic Papers, 51(1): 133-51. doi: 10.1093/oep/51.1.133 